\title{
Interactions of Heterotrophic Bacteria from Recycled Greenhouse Irrigation Water with Plant Pathogenic Pythium
}

\author{
Maria L. Burgos-Garay ${ }^{1}$ \\ Department of Plant Pathology \& Environmental Microbiology, Pennsylvania \\ State, 310 Buckhout Laboratory, University Park, PA 16802
}

Chuanxue Hong
Virginia Polytechnic Institute and State University, Hampton Roads Agricultural,
Research and Extension Center, Virginia Beach, VA 23455

Gary W. Moorman

Department of Plant Pathology \& Environmental Microbiology, Pennsylvania State, 310 Buckhout Laboratory, University Park, PA 16802

Additional index words. bacteria, greenhouse, Pythium

\begin{abstract}
Heterotrophic bacteria present in recycled greenhouse irrigation water (RIW) were characterized and then evaluated for their effect on Pythium aphanidermatum, $P$. cryptoirregulare, and $P$. irregulare. Nutrient agar (NA) and R2A agar were used to isolate copiotrophic and oligotrophic bacteria. Bacterial isolates recovered from RIW were categorized according to whether they inhibited Pythium growth, attached to hyphae, or enhanced Pythium growth in the three Pythium species used. Three bacterial isolates were selected to determine whether their in vitro interactions with Pythium aphanidermatum, the most pathogenic of the three species used, influenced disease development in the greenhouse. An isolate of Sphingobium sp. that inhibited Pythium, Pseudomonas sp. that attached to hyphae, and Cupriavidus sp. that enhanced the growth of $P$. aphanidermatum in vitro were used in greenhouse experiments to examine their effects on disease development in geranium (Pelargonium $\times$ hortorum 'White Orbit') grown in pasteurized potting mix in ebb and flood irrigation systems. Disease progress curves evaluating the effect of each bacterium indicate that they did not suppress or enhance disease development $(P=0.05)$. Thus, the effects that the bacterial isolates had in vitro differed from their effects under greenhouse conditions.
\end{abstract}

Recycling of irrigation water in commercial greenhouses is implemented as a strategy to minimize water and pesticide or fertilizer runoff from contaminating the environment (Hong and Moorman, 2005; Hu et al., 2008). However, recycling water increases the risk of accumulating and dispersing Pythium species that produce zoospores as well as other plant pathogens. This genus contains some phytopathogenic root pathogens that can cause severe losses in greenhouse crops, particularly those grown in soilless cultivation systems (Postma et al., 2005). Research that provides insights into the relationship among organisms of a microbial community in relation to Pythium spp. is important to build a better understanding of

\footnotetext{
Received for publication 26 Mar. 2014. Accepted for publication 1 May 2014.

Funding for this study was provided by the National Institute of Food and Agriculture-Specialty Crop Research Initiative of the U.S. Department of Agriculture, Agreement \#: 2010-51181-21140, and The Pennsylvania State University Agricultural Experiment Station.

Special thanks are extended to the two greenhouse operators who generously made their facilities available for this work and to Ms. Jessie Edson for her technical support.

${ }^{1}$ To whom reprint requests should be addressed; e-mailmlb483@psu.edu.
}

Pythium species (Uzuhashi et al., 2010) and their interaction with plants.

The coexistence of bacterial isolates that inhibit or enhance the growth of Pythium should be considered when investigating an ecosystem. Naturally occurring microorganisms have the ability to suppress diseases (Berger et al., 1996; Van Os \& Van Ginkel, 2001) even in soilless systems (Postma, 2009). Frequent coisolation of bacteria and Pythium and Phytophthora species suggests possible interspecies communication (Kong et al., 2010) and a close relationship among these groups of microbes and their ubiquitous coexistence may indicate a synchronous relationship with beneficial outcomes for one or both populations. Synergistic interaction studies between Pythium and conicheinhabiting microbes are few. It is unknown to what extent bacteria may play a role in the survival and spread of Pythium. Closer attention should be given to the interaction and outcome of different microorganisms, especially the highly managed greenhouse environment.

One biocontrol mode of action against Pythium in soil is described as a general suppression phenomenon (Hoitink et al., 1997; Pane et al., 2013) as a result of a diverse group of microorganisms and weak competitiveness of Pythium (Ho, 1986), although specific suppression phenomenon has also been described (Postma et al., 2009; Weller et al., 2002). In the aquatic environment, naturally occurring bacteria may play a role in the survival, suppression, or spread of Pythium. Therefore, the assessment of the microbial diversity in recycled irrigation water deserves attention. The stimulation of beneficial microorganisms known to survive in recycled irrigation water and able to suppress phytopathogenic Pythium species survival could be exploited as a treatment of recycled irrigation water in greenhouses.

The goal of this study was to identify Pythium-enhancing and Pythium-inhibiting bacteria residing in water being recycled in commercial greenhouses and determine if the in vitro effects of these bacteria on Pythium reflect their effects on disease development under greenhouse conditions.

\section{Material and Methods}

Pythium isolates. Isolates of three phytopathogenic Pythium species frequently found in commercial greenhouse crops in the northeastern United States were used for this study, Pythium aphanidermatum (Edson) Fitzp., P. cryptoirregulare (Garzón, Yánez, and Moorman), and $P$. irregulare Buisman. Cultures were maintained on colonized water agar (WA) blocks in sterile tap water tubes stored at room temperature. The WA blocks were transferred to potato dextrose agar (PDA) in petri plates to start active cultures. Subcultures were transferred to WA or PDA and incubated at room temperature for $3 \mathrm{~d}$ to use as inoculum for further testing.

Recycled irrigation water collection. RIW samples collected every $\approx 60 \mathrm{~d}$ for 3 years (2009-12) from cement tanks (23,000-L tank in Greenhouse A; 76,000-L tank in Greenhouse B) located inside two commercial greenhouses in Pennsylvania were processed to isolate heterotrophic bacteria. In both greenhouses, well water is used to initially fill the tanks. The only treatment of the water following irrigation is coarse filtration to prevent large particulates from entering the tanks. Both greenhouses produce a wide variety of bedding plants as well as poinsettias each year. Water was collected in sterile 1-L glass jars, near the surface (less than $1 \mathrm{~m}$ depth) and from the bottom (greater than $2 \mathrm{~m}$ depth) using a device that kept the jars sealed until they were at the desired depth. The jars were placed in a cooler containing ice packs that were not in direct contact with the jars and were transported to the laboratory. The dissolved oxygen level was immediately measured (Traceable ${ }^{\circledR}$ Digital Oxygen by Control Company, Friendswood, TX) at the time of collection. Electrical conductivity (Model SD-B15; Beckman Industrial) and $\mathrm{pH}$ (Mettler-Toledo SevenEasy model, Columbus, $\mathrm{OH}$ ) were measured after transport to the laboratory.

Heterotrophic bacteria from recycled water. Two media were used for isolation of bacteria, NA (Difco ${ }^{\mathrm{TM}}$ Nutrient Agar; Beckton, Dixon, and Co., Sparks, MD) for nonfastidious copiotrophic microorganisms and 

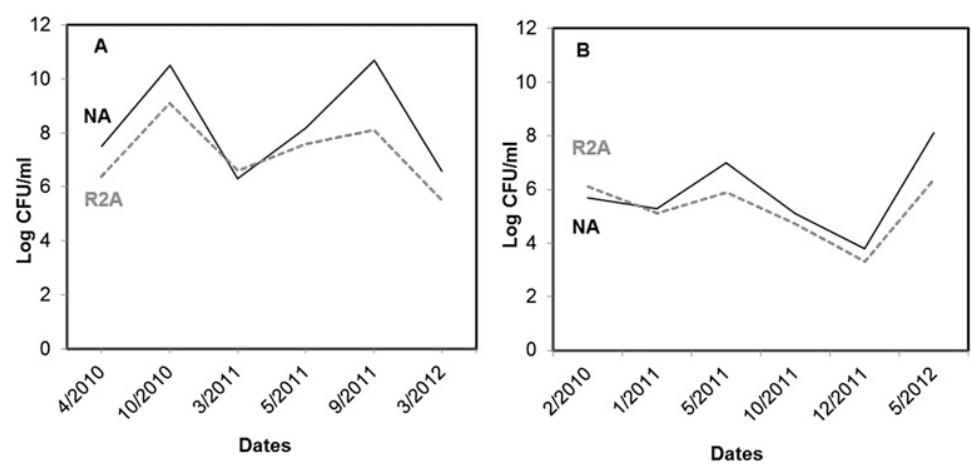

Fig. 1. Average colony-forming units (CFU) of copiotrophic bacteria on nutrient agar (NA) and oligotrophic bacteria on R2A isolated from recycled irrigation water in Greenhouse A (A) and Greenhouse B (B).
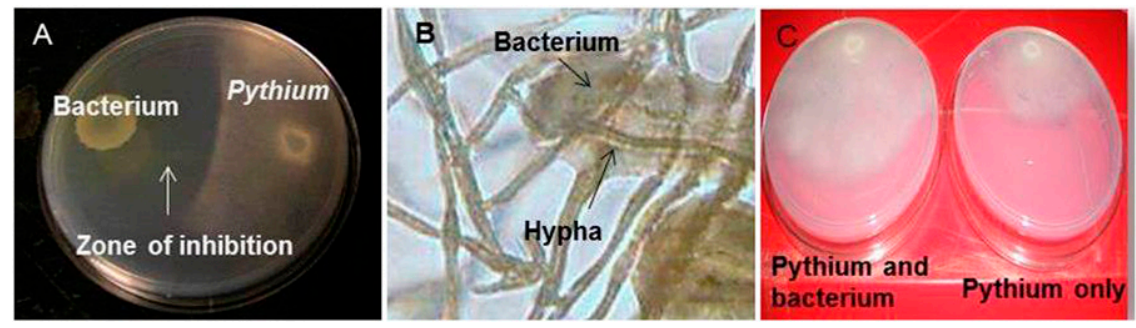

Fig. 2. Photos of three bacterial phenotypes. (A) Zone of inhibition of Pythium aphanidermatum by Sphingobium sp. (B) Microscopic view $(10 \times)$ of wet appearing $P$. irregulare hyphae caused by the attachment of Pseudomonas sp. (C) P. cryptoirregulare growth enhancing effect by Cupriavidus sp. in NA media.

R2A (Difco ${ }^{\text {TM }}$ R2A Agar; Beckton, Dixon, and Co.) for slow-growing oligotrophic microorganisms as follows. One milliliter of RIW was added to a glass tube containing $9 \mathrm{~mL}$ of sterile M9 ( $1 \times$ salt solution; $12.8 \mathrm{~g} \mathrm{Na}_{2} \mathrm{HPO}_{4}$; $3 \mathrm{~g} \mathrm{KH}_{2} \mathrm{PO}_{4} ; 0.5 \mathrm{mg} \mathrm{NaCl} ; 1.0 \mathrm{~g} \mathrm{NH}_{4} \mathrm{Cl}$, per 1 $\mathrm{L}$ of sterile water). Serial dilution up to $10^{-9}$ was used to determine colony-forming units per milliliter $(\mathrm{CFU} / \mathrm{mL})$ and to obtain individual, morphologically different colonies. Five hundred microliters from each dilution tube were transferred to NA and R2A media in petri plates and streaked with a sterile glass rod. NA plates were incubated at $23{ }^{\circ} \mathrm{C}$ for $3 \mathrm{~d}$ and R2A plates at $15^{\circ} \mathrm{C}$ for $7 \mathrm{~d}$. Morphologically different colonies were transferred to new media plates to obtain pure cultures. Each isolate was transferred to full-strength nutrient broth (NB; EMD Chemicals, Inc., Gibbstown, NJ) from NA plates and one-fourth strength NB from R2A plates and incubated at 23 and $15^{\circ} \mathrm{C}$, respectively. Fifty microliters from NB tubes were streaked on NA and R2A to confirm the purity of the culture. Pure cultures were transferred to NB tubes for future studies and for DNA extraction. Bacterial isolates were transferred to sterile tubes with silica gel granules (6 to 12 mesh, grade 40; Aqua Solutions, Deer Park, TX) for storage by mixing 1-week-old bacteria with $2.5 \mathrm{~mL}$ of sterile skim milk solution ( $10 \%$ skim milk and $15 \%$ glycerol) and applying this to the granules. These tubes were stored at $-80{ }^{\circ} \mathrm{C}$.

Pythium-bacterium in vitro interaction. To examine the in vitro effects of bacteria on Pythium, $50 \mu \mathrm{L}$ of 48 -h-old bacterial isolates from NB were placed on the margin of M9 minimum media agar $\left(12.5 \mathrm{~g} \mathrm{Na}_{2} \mathrm{HPO}_{4} ; 3 \mathrm{~g}\right.$
$\mathrm{KH}_{2} \mathrm{PO}_{4} ; 0.5 \mathrm{~g} \mathrm{NaCl} ; 1.0 \mathrm{~g} \mathrm{NH} \mathrm{NH}_{4}$; $1 \mathrm{M}$ $\mathrm{MgSO}_{4}, 1 \mathrm{M} \mathrm{MgSO} 4,2 \mathrm{~mL}$ of $20 \%$ glucose, per $1 \mathrm{~L}$ of sterile water) in petri plates and incubated at $21{ }^{\circ} \mathrm{C}$ in the dark. After $24 \mathrm{~h}$, a Pythium aphanidermatum, $P$. irregulare, or $P$. cryptoirregulare-colonized WA plug $(5 \mathrm{~mm}$ diameter) was placed on the opposite side of the plate containing the bacterium. Plates were incubated at $21^{\circ} \mathrm{C}$ for $3 \mathrm{~d}$ and observed daily. A clear zone of growth inhibition was used as an indication of a deleterious effect on the development of Pythium. After $72 \mathrm{~h}$, radii of the mycelial growth in the direction of the bacterium was measured and percentage of inhibition was calculated, $100 \times\left(\mathrm{R}_{1}-\mathrm{R}_{2}\right) / \mathrm{R}_{1}$, where $\mathrm{R}_{1}$ is the maximum radius of $P$. aphanidermatum, $P$. cryptoirregulare, or $P$. irregulare colonies in bacteria-free control plates and $\mathrm{R}_{2}$ is the radius of the colonies on the plates containing bacteria (Paulitz et al., 1992). A few bacterial isolates enhanced Pythium growth in vitro when compared with control plates (Pythium only). Enhancement of Pythium growth by bacterial isolates was calculated using a modified version of the equation above $100 \times\left(R_{2}-R_{1}\right) / R_{2}$. In addition, bacterial isolates that attached to and grew extensively on Pythium hyphae in media plates were isolated and kept for identification. Bacterial isolates that attached to Pythium grew next to the hyphae giving cultures a wet appearance in vitro. This wet growth was used as an initial indication of the bacterium-hyphal attachment phenotype, which was then confirmed using light microscopy and scanning electron microscopy (SEM). This attachment has been associated with a growth reduction of $P$. ultimum
(Nelson et al., 1986). In our study this phenotype was associated with a tendency to slow Pythium hyphal growth when compared with a control (Pythium only), but the inhibition was not statistically significant. A total of 900 isolates were tested in vitro. All bacterial isolates were tested at least three times and only isolates with consistent results were kept for identification.

Bacterium-hyphal attachment. One bacterium isolate $\left(756^{\wedge}-2 \quad 1.0 \mathrm{~N} .2\right.$ identified as Enterobacter sp.) was used as representative of the group of bacterial isolates identified as attaching to Pythium hyphae. Enterobacter sp. was incubated with $P$. aphanidermatum hyphae to verify attachment. Two samples were prepared under different conditions. One sample was incubated on solid medium agar containing glucose. In this method, a solid surface was needed on the medium to obtain an Enterobacter-P. aphanidermatum hyphal sample that could be further processed for SEM. A sterile crepe filter paper (VWR Grade 615 , West Chester, PA) was placed on the center of a $2 \%$ glucose M9 agar plate $(100 \times$ $65 \mathrm{~mm}$ ). One hundred microliters of a 24-h Enterobacter sp. was added to the medium around the edge of the filter. This plate was incubated at $25^{\circ} \mathrm{C}$ for $24 \mathrm{~h}$ at which time three 3-mm diameter WA plugs of a 24-h $P$. aphanidermatum were transferred to the edge of the filter on the M9 agar plate and incubated at $25^{\circ} \mathrm{C}$ for $3 \mathrm{~d}$. The filter was used to prepare the sample for SEM. In the second method used, a 24-h, 3-mm diameter WA plug of $P$. aphanidermatum was transferred to $20 \% \mathrm{~V} 8$ broth (V8 vegetable juice; Campbell Soup Co., Camden, NJ) for $3 \mathrm{~d}$. After $3 \mathrm{~d}$, the hyphal mat was transferred to a 24-h Enterobacter sp. culture grown on $9 \mathrm{~mL} \mathrm{NB}$ (1/100 dilution) and incubated at $25{ }^{\circ} \mathrm{C}$ for $3 \mathrm{~d}$. After $3 \mathrm{~d}$, all specimens were prepared for SEM to confirm the attachment of bacteria to Pythium hyphae.

SEM sample preparation. Briefly, samples were prepared according to Dykstra (1992). Samples were fixed overnight with $2.5 \%$ glutaraldehyde, washed three times with $0.1 \mathrm{M}$ phosphate buffer, and dehydrated in graded ethanol series $(25 \%, 50 \%, 70 \%, 85 \%, 95 \%$, and $100 \%$ ) for $5 \mathrm{~min}$ at each step. After dehydration, the samples were critical point-dried and coated with gold before being examined in a scanning electron microscope (JSM 5400, Peabody, MA).

Heterotrophic bacteria identification. To extract DNA, bacteria were grown in NB tubes and incubated at $21^{\circ} \mathrm{C}$ for $48 \mathrm{~h}$ and a modified thermal lysis DNA extraction method (QueipoOrtuno et al., 2008) was used. Briefly, $1 \mathrm{~mL}$ of bacterium culture in NB was transferred to a 2$\mathrm{mL}$ heat-resistant microcentrifuge tube and centrifuged (Eppendorf Model 5415C) at $15,000 \mathrm{~g}$ for $15 \mathrm{~min}$. The supernatant was discarded and the pellet was resuspended in 50 $\mu \mathrm{L}$ of sterile distilled water (SDW). Tubes were transferred to a heating block at $99^{\circ} \mathrm{C}$ for $10 \mathrm{~min}$, cooled on ice for $2 \mathrm{~min}$, and centrifuged at $15,000 \mathrm{~g} \times$ for $1 \mathrm{~min}$. Supernatant was transferred into a new tube and labeled. The DNA concentrations were measured using a NanoDrop 1000 spectrophotometer (Thermo 
Table 1. Identity and impact of bacterial isolates from recycled greenhouse irrigation water on three species of Pythium.

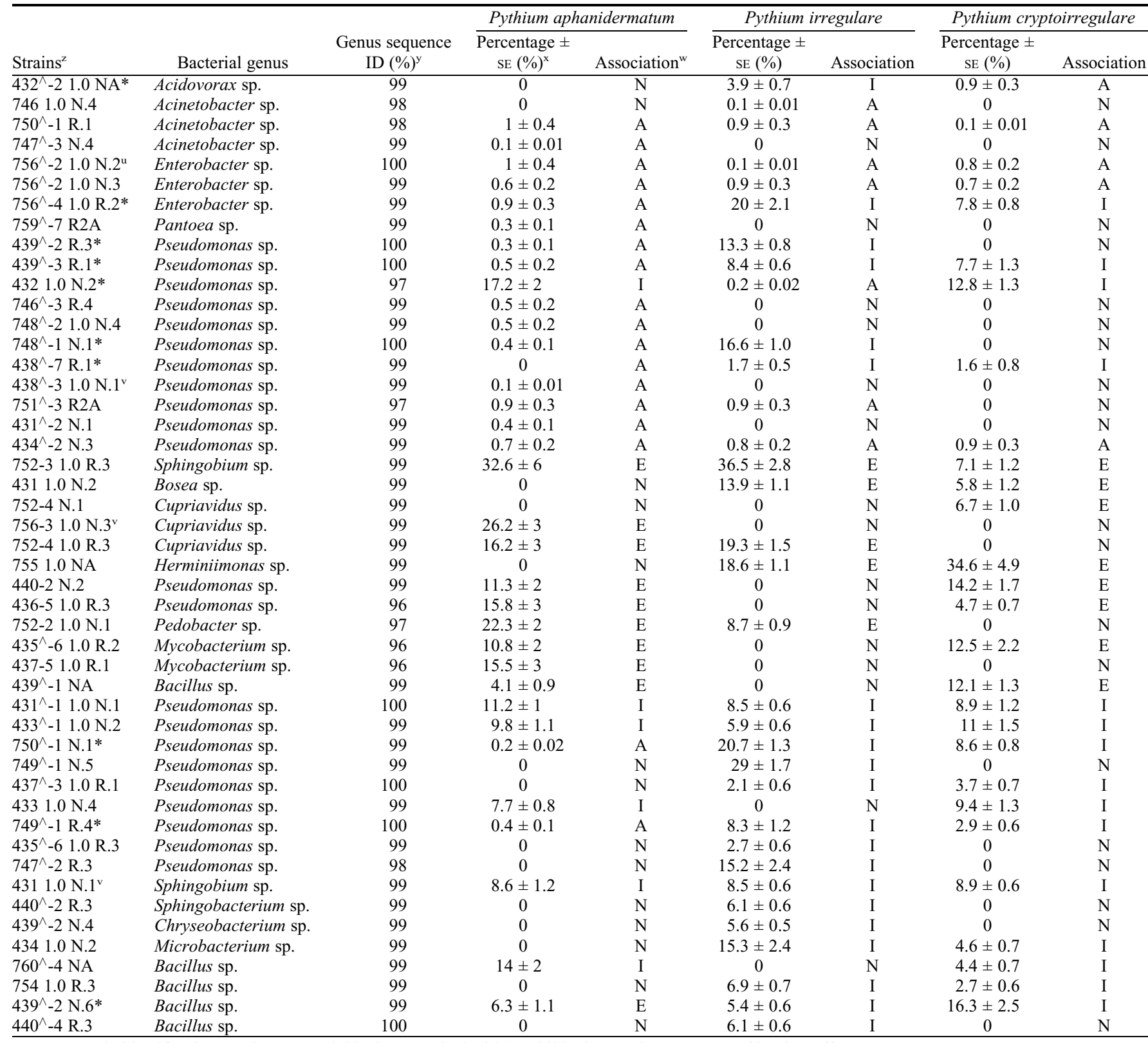

${ }^{2}$ Water sample identification number. Bacterial isolates marked with * exhibited more than one type of in vitro effect.

${ }^{\mathrm{y}}$ Percentage $16 \mathrm{~S}$ rDNA sequence identity similarity.

xPercentage of growth inhibition of Pythium was calculated using equation (Paulitz et al., 1992), $100 \times\left(\mathrm{R}_{1}-\mathrm{R}_{2}\right) / \mathrm{R}_{1}$, where $\mathrm{R}_{1}$ is the maximum radius of $P$ ythium colonies in bacteria-free control plates and $\mathrm{R}_{2}$ is the radius of the colonies on the plates containing bacteria. Percentage of Pythium growth enhancement by bacterial isolates was calculated using growth assessment equation (Paulitz et al., 1992) with modifications, $100 \times\left(R_{2}-R_{1}\right) / R_{2}$ where $R_{2}$ is the maximum radii of Pythium colonies in bacteria-inoculated plates and $\mathrm{R}_{1}$ is the radii of Pythium colonies in bacteria-free control plates. $\mathrm{N}=$ no enhancement, inhibition, or attachment to Pythium.

${ }^{\text {w} R e s u l t s ~ a c c o r d i n g ~ t o ~ i n ~ v i t r o ~ p h e n o t y p e: ~(I) ~ i n h i b i t i o n, ~(A) ~ a t t a c h m e n t, ~(E) ~ e n h a n c e m e n t ~ o f ~ P y t h i u m ~ s p p . ~ u s i n g ~ g r o w t h ~ a s s e s s m e n t ~ e q u a t i o n ~(P a u l i t z ~ e t ~ a l ., ~ 1992) ~}$ and $\mathrm{N}=$ no reaction.

Used in greenhouse experiments.

"Bacterium isolate used on scanning electron microscopy photograph as representative of the group attaching to Pythium hyphae.

Fisher Scientific, Waltham, MA) adjusted to $25 \mathrm{ng} \cdot \mu \mathrm{L}^{-1}$ with SDW, and stored at $-20{ }^{\circ} \mathrm{C}$ until further use.

The polymerase chain reaction (PCR) technique was used to amplify the coding region of the 16S rDNA gene of bacteria with semiuniversal primers EUBf933 (5'-GCACAA GCGGTGGAGCATGTGG-3') and EUBr1387 (5' -GCCCGGGAACGTATTCACCG-3') (Iwamoto et al., 2000). PCR master mix (Promega, Madison, WI) was used to carry out all the reactions as follow: $5 \mu \mathrm{L}$ of PCR
(10×) standard Taq buffer, $1 \mu \mathrm{L}$ of dNTPs (10 mM), $5 \mu \mathrm{L}$ of each $(10 \mu \mathrm{M})$ EUB f933/ EUBr1387 primer, $0.1 \mu \mathrm{L}(1.25 \mathrm{U})$ of Taq polymerase, $31.9 \mu \mathrm{L}$ of SDW, and $2 \mu \mathrm{L}$ of DNA template $\left(25 \mathrm{ng} \cdot \mu \mathrm{L}^{-1}\right)$ for a $50-\mu \mathrm{L}$ PCR reaction. PCR cycles were carried out in a PTC $-100^{\mathrm{TM}}$ or PTC $-200^{\mathrm{TM}}$ Programmable Thermal Controller (MJ Research, Waltham, MA) as follows: $95^{\circ} \mathrm{C}, 3 \mathrm{~min}$; 10 cycles of 94 ${ }^{\circ} \mathrm{C}$ for $30 \mathrm{~s}, 68^{\circ} \mathrm{C}$ for $45 \mathrm{~s}$, decreasing $1.0^{\circ} \mathrm{C}$ per cycle, $72{ }^{\circ} \mathrm{C}$ for $1 \mathrm{~min}$; followed by 25 cycles of $95{ }^{\circ} \mathrm{C}$ for $30 \mathrm{~s}, 58^{\circ} \mathrm{C}$ for $45 \mathrm{~s}, 72^{\circ} \mathrm{C}$ for $1 \mathrm{~min}$; finishing with an extension step of $72{ }^{\circ} \mathrm{C}$ for $5 \mathrm{~min}$. Electrophoresis was done on $2 \mu \mathrm{L}$ of $(6 \times)$ EZ-Vision ${ }^{\mathrm{TM}}$ Three, DNA dye Loading buffer (AMRESCO, Solon, $\mathrm{OH}$ ) mixed with $3 \mu \mathrm{L}$ of PCR product and loaded onto $1 \%$ agarose gel. Bands in the agarose gel were visualized in a ultraviolet translluminator (256 to $366 \mathrm{~nm}$ ) (UVP, LLC, Upland, CA).

PCR products were cleaned using ExoSAP (New England Biolabs, Ipswich, MA) following the manufacturer's instructions 
Table 2. Average measurements $(n=40)$ of recycled irrigation water $(\mathrm{RIW})$ samples collected from two commercial greenhouses in Pennsylvania and used in this study.

\begin{tabular}{|c|c|c|c|}
\hline \multirow[b]{2}{*}{ Description $^{z}$} & \multicolumn{3}{|c|}{ Chemical properties $^{\mathrm{y}}$} \\
\hline & $\mathrm{pH}$ & Dissolved oxygen $\left(\mathrm{mg} \mathrm{O}_{2} / \mathrm{L}\right)$ & Electrical conductivity $(\mathrm{mS} \cdot \mathrm{cm}-1)$ \\
\hline Mean & 6.16 & 4.13 & 1.49 \\
\hline Maximum & 7.8 & 6.5 & 2.9 \\
\hline Minimum & 5.3 & 2.0 & 0.3 \\
\hline$\underline{\mathrm{SD}}$ & \pm 0.447 & \pm 1.05 & \pm 0.40 \\
\hline
\end{tabular}

${ }^{\mathrm{z}}$ Results are for all samples from both greenhouses sampled.

${ }^{\mathrm{y}}$ Dissolved oxygen measurements were taken on site at the time of sampling. Electrical conductivity and pH measurements were taken in the laboratory.

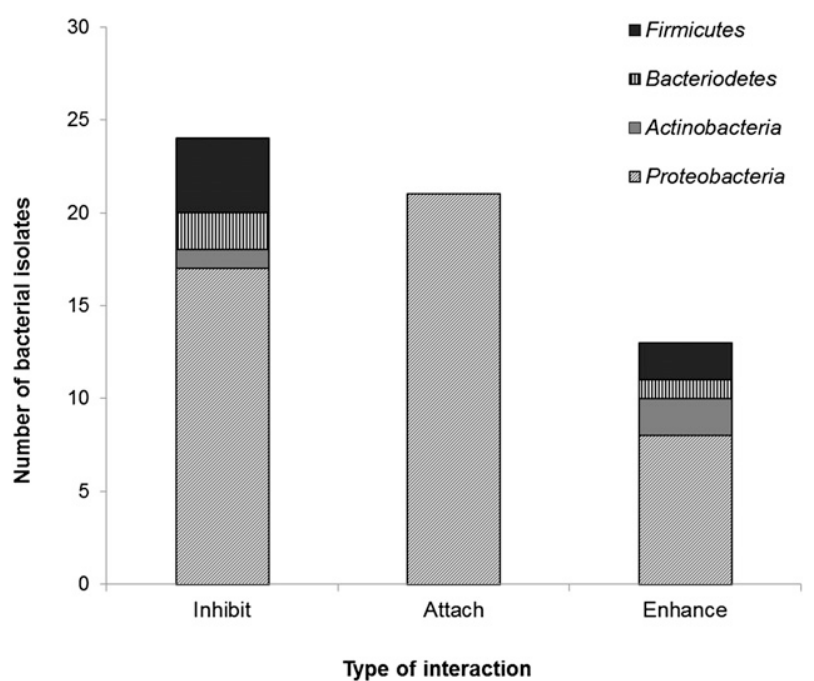

Fig. 3. Diversity and number of bacterial isolates from recycled irrigation water that inhibit, attach to, and enhance growth of Pythium spp. Identification was based on 16S rDNA sequences compared to sequences in GenBank database and Seqmatch from Ribosomal Database Project (Cole et al., 2009a).

and the DNA template was adjusted to 20 $\mathrm{ng} \cdot \mu \mathrm{L}^{-1}$ for sequencing. The same primers used for the initial PCR reaction were used for DNA sequencing. Briefly, $2 \mu \mathrm{L}$ of EUB f933/EUBr1387 $(1 \times)$ and $2 \mu \mathrm{L}$ of DNA template were transferred to a 96-well ltraAmp $^{\mathrm{TM}}$ PCR plate. DNA sequencing was conducted in an ABI Hitachi 3730XL DNA analyzer at The Pennsylvania State University Genomic Core Facility, University Park, PA. Bacterial sequences from the forward and reverse primers were aligned using Sequencher 5.0 (Gene Codes, Ann Harbor, MI) to construct a contig of the sequence for each bacteria isolate. DNA contigs were compared with $16 \mathrm{~S}$ rDNA gene sequences available using nucleotide BLAST from the National Center for Biotechnology Information GenBank and Seqmatch from the Ribosomal Database Project to identify the bacteria to genus (Cole et al., 2009).

Bacterial impacts on geranium stem rot in ebb and flood systems. To examine the effects of the bacteria on disease development, ebb and flood experimental units (American Hydroponics, Arcata, CA) were set up in a greenhouse at University Park, PA. One isolate, each representing a phenotype, Sphingobium (431 1.0 N.1; inhibited Pythium growth in vitro), Pseudomonas $\left(438^{\wedge}-31.0\right.$ N.1; attached to Pythium in vitro), and Cupriavidus $\left(756^{\wedge}-3\right.$ 1.0 N.3; enhanced Pythium growth in vitro), were tested against $P$. aphanidermatum. Seeds of geranium (Pelargonium $\times$ hortorum cv. White Orbit) were planted in pasteurized sphagnum peat/perlite potting mix (Fafard \#2; Conrad Fafard, Inc., Agawam, MA) in plastic seedling trays $(200$ cells/tray, $10 \mathrm{~mL} /$ cell) and grown in the laboratory for $5 \mathrm{~d}$ at $26^{\circ} \mathrm{C}$. The seedlings were then transferred to the greenhouse to acclimate. After $48 \mathrm{~h}$, seedlings were transplanted to individual round, plastic pots $(10 \mathrm{~cm}$ diameter $\times 8.5 \mathrm{~cm})$ containing $\approx 400 \mathrm{~mL}$ of pasteurized Fafard \#2 potting mix. Each experimental unit consisted of 16 pots (four rows of four pots) in a $1 \mathrm{~m} \times 1-\mathrm{m}$ plastic ebb and flood bench. Each bench had its own 30-L water reservoir and pump. Tap water containing soluble fertilizer $(15 \% \mathrm{~N}-16 \%$ $\mathrm{P}_{2} \mathrm{O}_{5}-17 \% \quad \mathrm{~K}_{2} \mathrm{O}$; Peters Professional; The Scotts Company LLC, Marysville, $\mathrm{OH}$ ) filled each reservoir. After 1 week, selected unit reservoirs were inoculated with a 48-h-old bacterium culture $\left(10^{5} \mathrm{CFU} / \mathrm{mL}\right.$, final concentration). Each bacterium was cultured in 10 Erlenmeyer flasks $(250 \mathrm{~mL})$. One milliliter of a 24-h-old NB bacterium culture was added to $100 \mathrm{~mL} \mathrm{NB}$ and incubated at $23^{\circ} \mathrm{C}$. After $48 \mathrm{~h}$, the broth was centrifuged at $5000 \mathrm{~g}$ for $3 \mathrm{~min}$. Bacterial pellets were diluted into $15 \mathrm{~mL}$ of M9 minimum media and use to inoculate ebb and flood systems. Five hundred microliters of the $15 \mathrm{~mL}$ broth was plated into M9 to quantify bacterial inoculum $\left(10^{6}\right.$ to $\left.10^{7}\right)$. The next week, units were inoculated with a 5- or 7-d-old $P$. aphanidermatum culture applied to the surface of the potting mix close to the stem (stem inoculum) or directly into the water reservoir (water inoculum), respectively. Pythium aphanidermatum, the most pathogenic of the three species, was grown at $23{ }^{\circ} \mathrm{C}$ on NARF $(25 \mathrm{mg}$ nystatin, $150 \mathrm{mg}$ ampicillin, $5 \mathrm{mg}$ rifampicin, 5 $\mu \mathrm{L}$ fluazinam; $500 \mathrm{~mL}$ of $20 \%$ clarified V8 juice agar) (Morita and Tojo, 2007) plates for stem inoculations and $25 \mathrm{~mL}$ of $20 \%$ clarified V8 juice for water inoculations. The contents of one $60-\mathrm{mm}$ diameter plate of colonized NARF agar was mixed using a blender (Waring Commercial, Torrington, CT) with $100 \mathrm{~mL}$ of sterile water to obtain Pythium stem inoculum. For Pythium water inoculum, V8 broth plates were washed three times with SDW and the Pythium mat was added to the water reservoir. We used experimental units with bacterium-only and non-treated units as controls. When Pythium was applied to plants (stem inoculum) in pots, eight plants were inoculated. Electronic timers controlled the pumps such that they ran for $\approx 10 \mathrm{~min}$ at each irrigation. An outflow pipe connected to the reservoir allowed the water to reach a depth of $\approx 2 \mathrm{~cm}$ in the ebb and flood tray before it began to drain back into the reservoir. The reservoirs were adjusted to $30 \mathrm{~L}$ with fertilizer-containing water and kept at that volume for the duration of the experiment. To monitor the presence of Pythium, all reservoirs were baited with blades of creeping bentgrass (Agrostis stolonifera $\mathrm{L}$. 'Penn Eagle') that had been grown in the laboratory (Watanabe et al., 2008). Grass blades cut into sections were sandwiched between pieces of fiberglass window screen and suspended in the water. The blades were changed weekly in all systems. Blades were taken to the laboratory and individually placed on NARF agar for detection of Pythium. Pythium growing from the blades was transferred to water agar and identified weekly to verify the survival of $P$. aphanidermatum. In addition, to monitor the amount of bacteria, $5 \mathrm{~mL}$ of water was extracted from each system weekly and plated in NA media.

Greenhouse experimental units were arranged in a randomized complete block design. Each treatment was replicated twice with each replicate consisting of 16 geranium plants. The experiment was done from Jan. to Mar. 2012 and repeated from Apr. to June 2012. The number of geraniums infected per week was recorded based on water-soaked lesions on stems for each experimental unit. Disease incidence (DI) percentage was calculated based on the number of plants infected/total number of plants $\times 100$ per experimental unit. The reduction of DI, as a measurement of effectiveness of the treatment in suppressing the 

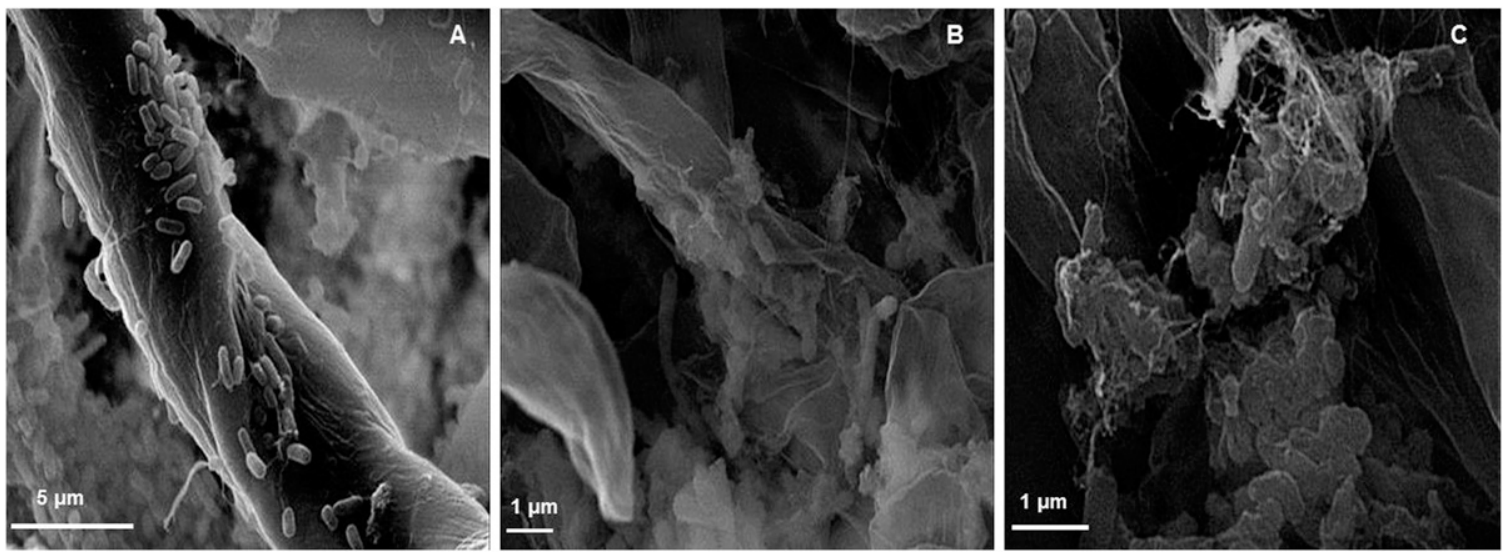

Fig. 4. Scanning electron micrographs of Pythium aphanidermatum and Enterobacter sp. from two specimen preparations. A) Specimen incubated over crepe filter paper on 2\% M9 agar for $3 \mathrm{~d}$, and $\mathbf{B}$ ) and $\mathbf{C}$ ) Specimens incubated on nutrient broth for $3 \mathrm{~d}$.

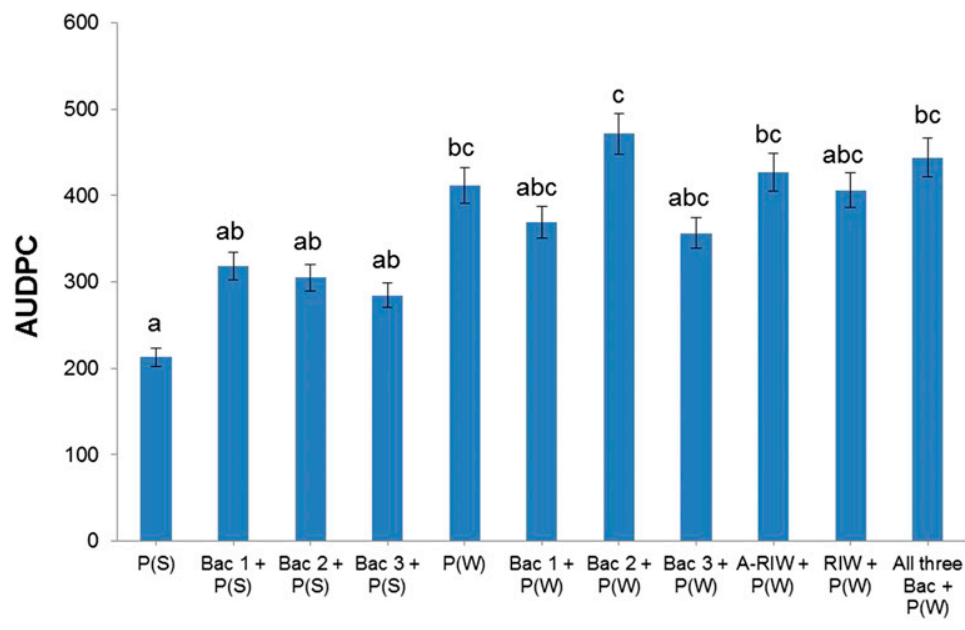

Water samples

Fig. 5. Mean area under the progress curve (AUDPC) of geranium stem rot in ebb and flow systems infested by adding mycelium mat of Pythium aphanidermatum to either potting mix $[\mathrm{P}(\mathrm{S})]$ or water reservoir $[\mathrm{P}(\mathrm{W})]$. Bacterial species and strains: Sphingobium sp., 431 1.0 N.1 (Bac 1), Pseudomonas sp., 438^-3 1.0 N.1 (Bac 2), Cupriavidus sp., and 756^-3 1.0 N.3 (Bac 3), were added alone or in combination to a reservoir to examine antagonistic activities. Recycled irrigated water (RIW) and autoclaved recycled irrigated water (A-RIW) representing the presence and absence of total bacterial community also were included with $\mathrm{P}(\mathrm{W})$ for comparison purposes. Error bars represent the standard error of the mean. The graph shows the mean AUDPC of two independently performed experiments. Bars showing same letter are not significantly different (Kruskal-Wallis test, $P=0.05$ ).

disease progress, was assessed using data plotted as area under the disease progress curve (AUDPC). AUDPC were calculated with the trapezoidal equation (Madden et al., 2007) using DI over time. In this method, DI data are collected over time. The average DI at the midpoint between two points is calculated by multiplying the average by the length of time between two points and summing the products across all time intervals.

Data analysis. Heterotrophic bacteria counts were log-transformed before analysis. The AUDPC data did not meet normal distribution, even after transformation with the arscine square root. Therefore, the data were analyzed with Kruskal-Wallis test $(P=0.05)$ using XLSTAT 2013 (Addinsoft, France). This method is a nonparametric approach for comparing data similar to analysis of variance (Sokal and Rohlf, 2012).

\section{Results}

Quantity of heterotrophic bacteria in greenhouse water reservoir. Two media were used to isolate heterotrophic fast-growing, non-fastidious copiotrophic bacteria and slowgrowing oligotrophic bacteria from recycled irrigation water collected at two different commercial greenhouses.

The quantities of heterotrophic bacteria (CFU/mL) differed between greenhouses (Fig. 1). Usually, bacterial numbers were higher in the fall in Greenhouse A and in the spring in Greenhouse B coinciding with higher crop production in the respective greenhouses. Overall, Greenhouse A had higher numbers of heterotrophic bacteria in $60 \%$ of the water samples (Fig. 1). The quantities of copiotrophic and oligotrophic bacteria differed. Water samples from Greenhouse A had 60\% more $\mathrm{CFU} / \mathrm{mL}$ of copiotrophic bacteria, whereas $50 \%$ of the samples had more oligotrophic bacteria.

Many morphologically different bacteria colonies were isolated from the RIW samples and $\approx 900$ bacterial isolates were tested for their in vitro effect on the hyphae of the three Pythium species (Fig. 2). Whereas only 5\% of the isolates exhibited inhibition, attachment to, or enhancement of Pythium growth (Table $1)$, they were isolated repeatedly from the greenhouses. The $\mathrm{pH}$, electrical conductivity, and dissolved oxygen content of the water collected from two commercial greenhouses (Table 2) are within ranges that maintain bacterial growth.

Pythium-bacterium in vitro interaction. Twenty-four bacterial isolates inhibited the growth of at least one of the Pythium species (Table 1). The group was dominated by Gramnegative bacteria Proteobacteria and Bacteriodetes, whereas few isolates were Gram-positive Actinobacteria and Firmicutes (Fig. 3). Among the antagonistic bacteria, 14 were identified as Pseudomonas, four as Bacillus, and one isolate of each as Microbacterium, Sphingobacterium, Enterobacter, Sphingobium, or Acidovorax. We isolated bacteria that inhibited only one species, $P$. irregulare, $P$. cryptoirregulare, or $P$. aphanidermatum. Some bacterial isolates exhibited multiple effects, attaching to one Pythium species while inhibiting the growth of another Pythium species.

Twenty-one bacterial isolates, dominated by Proteobacteria (Fig. 3), attached to Pythium hyphae in vitro (Table 1). Most of the bacterial isolates that attached to Pythium hyphae decreased the growth of Pythium when compared with control plates, although the inhibition was not significant. Most of the isolates identified as Pseudomonas spp. specifically attached to $P$. aphanidermatum hyphae. Some bacterial isolates had multiple effects (attached to or inhibited Pythium) depending on the Pythium species. Acinetobacter spp. 
isolates were closely related but not identical to one another. That was also the case for Enterobacter spp. Pseudomonas spp. isolates were very diverse. SEM of the $P$. aphanidermatum-Enterobacter sp. interaction confirmed that bacterial cells actually attached to $P$. aphanidermatum hyphae (Fig. 4). In Figure 4A, an intact hyphae can be seen with bacterial cells attached to the surface. In Figures 4B and 4C, P. aphanidermatum hyphae can be seen with bacterial cells aggregated near to a lyzed hyphae. A similar association was observed with $P$. irregulare and Enterobacter sp.

Thirteen bacterial isolates enhanced the growth of Pythium in vitro (Table 1). Most were Gram-negative (Proteobacteria and Bacteriodetes) and a few were Gram-positive bacteria (Firmicutes and Actinobacteria) (Fig. 3). Pythium aphanidermatum growth was enhanced by $77 \%$ of the isolates, $62 \%$ enhanced the growth of $P$. cryptoirregulare, whereas $38 \%$ enhanced the growth of $P$. irregulare. One bacterium, identified as $\mathrm{Ba}$ cillus sp., enhanced the growth of $P$. aphanidermatum but inhibited the growth of $P$. cryptoirregulare and $P$. irregulare.

Area under the disease progress curve. Disease symptoms caused by $P$. aphanidermatum developed 2 weeks after inoculating the units with the pathogen. Initial symptoms included stunting and water-soaked lesions on stems close to the soil line. Lesions on the stem progressed and eventually killed the plants. The systems with the least mortality (less than $40 \%$ ) were those in which Pythium was applied to the potting mix (stem inoculum) and no bacteria had been added. $P$. aphanidermatum was detected in the units from the time of inoculation until 1 week after the plants were dead. Bacteria quantities were between $10^{4}$ and $10^{6} \mathrm{CFU} / \mathrm{mL}$ in all experimental units throughout the experiment. AUDPC value was highest in the experimental unit with Pseudomonas and $P$. aphanidermatum added to water and in the unit with all three bacteria and $P$. aphanidermatum in water (Fig. 5), but not different from most of the experimental units. None of the bacteria suppressed Pythium aphanidermatum that caused disease in geraniums under greenhouse conditions.

\section{Discussion}

The RIW from two commercial greenhouses was sampled over a 2 -year period to identify those bacterial isolates with in vitro effects on Pythium aphanidermatum, P. cryptoirregulare, or $P$. irregulare. Water from both greenhouses had up to $10^{9} \mathrm{CFU} / \mathrm{mL}$ of bacteria. Although two different media were used, one that favored copiotrophic bacteria and the other oligotrophic bacteria, most of the genera identified were isolated on both media. It is known that some genera can switch from copiotrophic to oligotrophic growth depending on the environmental conditions (Lauro et al., 2009). Microbial growth in nature is often characterized as "nutrient-limited" (Schmidt and Konopka, 2009), which explains the mechanism of some microorganisms switching, depending on nutrient availability in the environment, and may explain why we isolated the same genera from both media. Although the two commercial greenhouses are geographically separated and have different sources of irrigation water, they harbored similar bacteria phyla in the water that was being recycled during crop production.

Among the over 900 selected heterotrophic bacteria evaluated, only a small group was identified as having in vitro effects on the growth of any of the three plant pathogenic Pythium species. Previous studies of the major phyla known to suppress Pythium spp. include Pseudomonas (Gammaproteobacteria) (Chen et al., 2012; Gardener, 2007), Enterobacter (Gammaproteobacteria) (Chen et al., 2012; Martin and Loper, 1999), and Bacillus (Firmicutes) (Chen et al., 2012). In this study, most of the heterotrophic bacteria isolated with antagonistic properties were identified as Proteobacteria, Bacteriodetes, Actinobacteria, and Firmicutes. The bacteria genera isolated in this study have been identified as containing species that act as biocontrol agents (Brooks et al., 1994; Nelson et al., 1986; Silva et al., 2012) against Pythium (Deniel et al., 2004; Mavrodi et al., 2012). The most abundant genus was Pseudomonas, which is known for its root-colonizing ability (Paulitz et al., 1992) and for its antagonistic properties against Pythium (Chen et al., 1998, 2012; Gardener, 2007). It was not surprising to find Pseudomonas species because they are widespread in the environment (Valerio et al., 2010), including aquatic ecosystems. Furthermore, these results suggest that Pseudomonas and other bacteria survived well under greenhouse conditions.

We identified some bacterial isolates that were able to attach to Pythium hyphae, mainly $P$. aphanidermatum, and exhibited a tendency to slow their growth in vitro, although the inhibition was not significant. This phenomenon has received sporadic attention (Leben, 1984; Siala and Gray, 1974; Wong and Griffin, 1976). Previous studies mention the ability of bacteria to attach to fungi (Nguyen Duc et al., 2011; Scheublin et al., 2010) and Pythium hyphae and inhibit their growth (Nelson et al., 1986). We observed the same association because Pythium grew slower in the presence of attached bacteria. Recently, a newly identified root-colonizing bacterium was found to attach to $P$. aphanidermatum hyphae infecting cucumber seed (Ofek et al., 2012). It is not clear what this relationship represents but the specificity to $P$. aphanidermatum, a highly phytopathogenic species, by the bacterium deserves further investigation.

A surprising finding was the identification of bacterial isolates that stimulate the growth of the three Pythium isolates. To our knowledge, this is the first report of this phenomenon. It is not known to what extent bacterial isolates enhance the survival of $P$. aphanidermatum, $P$. cryptoirregulare, and $P$. irregulare in RIW reservoirs, but this should be explored. We have no evidence of why these organisms enhanced the growth of Pythium in vitro or if this occurs under natural conditions.

A few bacterial isolates exhibited different interactions with the different Pythium species. In the present research, Bacillus was identified for its in vitro ability to enhance the growth of $P$. aphanidermatum and inhibit growth of $P$. irregulare and $P$. cryptoirregulare. This highlights the complexity of the outcome of the interaction of different bacteria and different Pythium species. It should not be assumed that an agent that controls one pathogen will have the same or similar impact on other pathogens in the same genus.

Pythium disease suppression was not observed with any of the three bacterial isolates used in the greenhouse experiment. In systems inoculated by placing Pythium in water, including systems inoculated with bacterial isolates, there was a tendency toward enhanced Pythium aphanidermatum-caused disease in geranium, although this was not significant. In terms of disease severity rather than incidence, the most severe symptoms were observed in the experimental units inoculated with any of the three bacterial isolates and Pythium directly in the water reservoir. Synergistic relationships between Pythium and bacterial isolates have been observed previously suggesting that bacteria may predispose plants to Pythium (Paulitz et al., 1992). This suggests that the bacteria-Pythium interaction is complex and may not be predicted by in vitro tests (Folman et al., 2003; Pliego et al., 2011). This is an important area of research because it raises questions about the outcome of the introduction of bacteria into new environments, especially when bacteria-fungi and bacteria-Pythium interactions are discovered.

In conclusion, we found that a variety of heterotrophic bacteria reside in recycled irrigation in commercial greenhouses in Pennsylvania. The ecosystem sustained bacteria that inhibited, attached to, or enhanced Pythium hyphae in vitro, but these interactions did not occur in greenhouse plant inoculation studies. In the present research, three bacteria were selected from the microbial community found in RIW from commercial greenhouses. They were introduced into what was probably a much simpler, less microbially diverse environment in an experimental greenhouse. The in vitro effects of the individual bacteria on Pythium did not coincide with their effects under greenhouse conditions. Further investigations are needed to determine whether a more complex microbial community would have different effects on Pythium and on disease development. Investigations such as this will become more important as more greenhouse growers adopt RIW technologies.

\section{Literature Cited}

Berger, F., H. Li, D. White, R. Frazer, and C. Leifert. 1996. Effect of pathogen inoculum, antagonist density, and plant species on biological control of Phytophthora and Pythium damping-off by Bacillus subtilis Cot1 in high-humidity fogging glasshouses. Phytopathology 86:428-433.

Brooks, D.S., C.F. Gonzalez, D.N. Appel, and T.H. Filer. 1994. Evaluation of endophytic bacteria 
as potential biological control agents for oak wilt. Biol. Control 4:373-381.

Chen, C.Q., R.R. Belanger, N. Benhamou, and T.C. Paulitz. 1998. Induced systemic resistance (ISR) by Pseudomonas spp. impairs pre- and post-infection development of Pythium aphanidermatum on cucumber roots. Eur. J. Plant Pathol. 104:877-886.

Chen, M.H., A.L. Jack, I.C. Mcguire, and E.B. Nelson. 2012. Seed-colonizing bacterial communities associated with the suppression of Pythium seedling disease in a municipal biosolids compost. Phytopathology 102:478-489.

Cole, J.R., Q. Wang, E. Cardenas, J. Fish, B. Chai, R.J. Farris, A.S. Kulam-Syed-Mohideen, D.M. McGarrell, T. Marsh, G.M. Garrity, and J.M. Tiedje. 2009. The Ribosomal Database Project: Improved alignments and new tools for rRNA analysis. Nucleic Acids Res. 37:141-145.

Deniel, F., P. Rey, M. Cherif, A. Guillou, and Y. Tirilly. 2004. Indigenous bacteria with antagonistic and plant-growth-promoting activities improve slowfiltration efficiency in soilless cultivation. Can. J. Microbiol. 50:499-508.

Dykstra, M.J. 1992. Biological electron microscopy: Theory, techniques, and troubleshooting. Plenum Press, New York, NY.

Folman, L.B., J. Postma, and J.A. Van Veen. 2003. Inability to find consistent bacterial biocontrol agents of Pythium aphanidermatum in cucumber using screens based on ecophysiological traits. Microb. Ecol. 45:72-87.

Gardener, B.B.M. 2007. Diversity and ecology of biocontrol Pseudomonas spp. in agricultural systems. Phytopathology 97:221-226.

Ho, H.H. 1986. Pythium dimorphum from Rhododendron. Mycopathologia 93:141-145.

Hoitink, H.J., A.G. Stone, and D.Y. Han. 1997. Suppression of plant diseases by composts. HortScience 32:184-187.

Hong, C.X. and G.W. Moorman. 2005. Plant pathogens in irrigation water: Challenges and opportunities. Crit. Rev. Plant Sci. 24:189208.

Hu, J.H., C.X. Hong, E.L. Stromberg, and G.W. Moorman. 2008. Mefenoxam sensitivity and fitness analysis of Phytophthora nicotianae isolates from nurseries in Virginia, USA. Plant Pathol. 57:728-736.

Iwamoto, T., K. Tani, K. Nakamura, Y. Suzuki, M. Kitagawa, M. Eguchi, and M. Nasu. 2000. Monitoring impact of in situ biostimulation treatment on groundwater bacterial community by DGGE. FEMS Microbiol. Ecol. 32:129-141.

Kong, P., B.W.K. Lee, Z.S. Zhou, and C.X. Hong. 2010. Zoosporic plant pathogens produce bacterial autoinducer-2 that affects Vibrio harveyi quorum sensing. FEMS Microbiol. Lett. 303:5560.

Lauro, F.M., D. McDougald, T. Thomas, T.J. Williams, S. Egan, S. Rice, M.Z. DeMaere, L. Ting, H. Ertan, J. Johnson, S. Ferriera, A. Lapidus, I. Anderson,
N. Kyrpides, A.C. Munk, C. Detter, C.S. Han, M.V. Brown, F.T. Robb, S. Kjelleberg, and R. Cavicchioli. 2009. The genomic basis of trophic strategy in marine bacteria. Proc. Natl. Acad. Sci. USA 106:15527-15533.

Leben, C. 1984. Spread of plant pathogenic bacteria with fungal hyphae. Phytopathology 74 : 983-986.

Madden, L.V., G. Hughes, and F. Van Den Bosch. 2007. The study of plant disease epidemics. APS Press, St. Paul, MN.

Martin, F.N. and J.E. Loper. 1999. Soilborne plant diseases caused by Pythium spp: Ecology, epidemiology, and prospects for biological control. Crit. Rev. Plant Sci. 18:111-181.

Mavrodi, O.V., N. Walter, S. Elateek, C.G. Taylor, and P.A. Okubara. 2012. Suppression of Rhizoctonia and Pythium root rot of wheat by new strains of Pseudomonas. Biol. Control 62:93102.

Morita, Y. and M. Tojo. 2007. Modifications of PARP medium using fluazinam, miconazole, and nystatin for detection of Pythium spp. in soil. Plant Dis. 91:1591-1599.

Nelson, E.B., W.L. Chao, J.M. Norton, G.T. Nash, and G.E. Harman. 1986. Attachment of Enterobacter cloacae to hyphae of Pythium ultimum, possible role in the biological control of Pythium preemergence damping-off. Phytopathology 76: 327-335.

Nguyen Duc, C., M.H. Nicolaisen, J. Sorensen, and S. Olsson. 2011. Hyphae-colonizing Burkholderia sp.-A new source of biological control agents against sheath blight disease (Rhizoctonia solani AG1-IA) in rice. Microb. Ecol. 62:425434.

Ofek, M., Y. Hadar, and D. Minz. 2012. Ecology of root colonizing Massilia (Oxalobacteraceae). PLoS One 7.

Pane, C., A. Piccolo, R. Spaccini, G. Celano, D. Villecco, and M. Zaccardelli. 2013. Agricultural waste-based composts exhibiting suppressivity to diseases caused by the phytopathogenic soil-borne fungi Rhizoctonia solani and Sclerotinia minor. Appl. Soil Ecol. $65: 43-51$.

Paulitz, T.C., T. Zhou, and L. Rankin. 1992. Selection of rhizosphere bacteria for biological control of Pythium aphanidermatum on hydroponically grown cucumber. Biol. Control 2:226-237.

Pliego, C., C. Ramos, A. De Vicente, and F.M. Cazorla. 2011. Screening for candidate bacterial biocontrol agents against soilborne fungal plant pathogens. Plant Soil 340:505-520.

Postma, J. 2009. The status of biological control of plant diseases in soilless cultivation, p. 133146. In: Recent developments in management of plant diseases. Springer, Torino, Italy.

Postma, J., B.P.J. Geraats, R. Pastoor, and J.D. Van Elsas. 2005. Characterization of the microbial community involved in the suppression of
Pythium aphanidermatum in cucumber grown on rockwool. Phytopathology 95:808-818.

Postma, J., L.H. Stevens, G.L. Wiegers, E. Davelaar, and E.H. Nijhuis. 2009. Biological control of Pythium aphanidermatum in cucumber with a combined application of Lysobacter enzymogenes strain 3.1T8 and chitosan. Biol. Control 48:301-309.

Queipo-Ortuno, M.I., J.D.D. Colmenero, M. Macias, M.J. Bravo, and P. Morata. 2008. Preparation of bacterial DNA template by boiling and effect of immunoglobulin $\mathrm{G}$ as an inhibitor in real-time PCR for serum samples from patients with brucellosis. Clin. Vaccine Immunol. 15:293-296.

Scheublin, T.R., I.R. Sanders, C. Keel, and J.R. Van Der Meer. 2010. Characterisation of microbial communities colonising the hyphal surfaces of arbuscular mycorrhizal fungi. ISME J. 4:752-763.

Schmidt, T.M. and A.E. Konopka. 2009. Physiological and ecological adaptations of slowgrowing, heterotrophic microbes and consequences for cultivation, p. 101-120. In: Epstein SS (ed.). Uncultivated microorganisms. Springer, Berlin, Germany.

Siala, A. and T.R.G. Gray. 1974. Growth of Bacillus subtilis and spore germination in soil observed by fluorescent antibody techniques. J. Gen. Microbiol. 81:191-198.

Silva, H.S.A., J.P.L. Tozzi, C.R.F. Terrasan, and W. Bettiol. 2012. Endophytic microorganisms from coffee tissues as plant growth promoters and biocontrol agents of coffee leaf rust. Biol. Control 63:62-67.

Sokal, R.R. and F.J. Rohlf. 2012. Biometry. W.H. Freeman and Co., New York, NY.

Uzuhashi, S., M. Tojo, and M. Kakishima. 2010. Phylogeny of the genus Pythium and description of new genera. Mycoscience 51:337-365.

Valerio, E., S. Chaves, and R. Tenreiro. 2010. Diversity and impact of prokaryotic toxins on aquatic environments: A review. Toxins 2:2359-2410.

Van Os, G.J. and J.H. Van Ginkel. 2001. Suppression of Pythium root rot in bulbous Iris in relation to biomass and activity of the soil microflora. Soil Biol. Biochem. 33:14471454.

Watanabe, H., K. Kageyama, Y. Taguchi, H. Horinouchi, and M. Hyakumachi. 2008. Bait method to detect Pythium species that grow at high temperatures in hydroponic solutions. J. Gen. Plant Pathol. 74:417-424.

Weller, D.M., J.M. Raaijmakers, B.B.M. Gardener, and L.S. Thomashow. 2002. Microbial populations responsible for specific soil suppressiveness to plant pathogens. Annu. Rev. Phytopathol. 40:309-348.

Wong, P.T.W. and D.M. Griffin. 1976. Bacterial movement at high matric potentials. 1. Artificial and natural soils. Soil Biol. Biochem. 8:215-218. 